\title{
Recycling Of Ceramic Refractory Materials: Process Steps
}

\author{
H. Baloyi, Bm Thethwayo And Antoine F. Mulaba - Bafubiandi
}

\begin{abstract}
The disposal of refractory materials has become a major problem for metal producers. Ceramic furnace tubes are quite costly, yet they are prone to cracking and wear due to chemical reactions and thermal shock. Suppliers do not accept back these tubes after use hence the need for ways to recycle and reuse these tubes since they affect the environment negatively if they are dumped in landfills. Refractory materials containing copper, magnesite, chrome and bauxite cause environmental impacts. Chromium (VI) can cause cancer when disposed off into the environment. Wastes containing chromium are considered high-risk materials, therefore, products containing chromium cannot be disposed off. Spent furnace tubes (alumina) were collected from pyrometallurgical laboratory. They were either broken due to thermal cycling or chemical reactions. Hand-sorted, crushed and milled the resulting product was screened to determine the particle size distribution. The powder that was recovered was $>98 \%$ wt $\%$ alumina. These can be used as raw materials for the manufacturing of crucibles. This paper elaborates on recycling process stages or steps that the spent ceramic furnace tubes undergoes for them to be successfully recycled, leading into the reduction in the impact of dumping hazardous spent ceramic refractory into landfills. Production of chromium bearing alloys will be explained as magnesia-chrome are recycled as scrap.
\end{abstract}

Keywords-Ceramic materials, furnace, process stages, refractory recycling.

\section{INTRODUCTION}

Environment is a very important natural factor on earth. Every plant or a mine that is in operation must be aware of the damages they are causing to the environment. This also includes the health of living and non-living things on earth (Magesh, Pappayee, \& Santhosh, 2016).

In recent years, the refractories have been causing the environmental problems, this has become an increasingly important issue. The spent refractory materials disposal has become a major problem for the metal producers. Most common refractory materials contain bauxite, copper, magnesite and chrome-bearing materials in cement industries. These materials have a huge impact to the environment. These refractories are regarded as hazardous materials (Magesh, Pappayee, \& Santhosh, 2016).

In high temperature processes, Chrome- bearing refractories are the best suitable. The disposal of these materials to the environment can cause cancer to human beings (Magesh, Pappayee, \& Santhosh, 2016). $\left(\mathrm{Cr}_{2} \mathrm{O}_{3}\right)$ can be oxidized to $\mathrm{Cr}$ $\left(\mathrm{CrO}_{4}{ }^{-2}\right.$, refractory materials containing chromium have more problems as harmful hexavalent chromium ions may be formed

H. Baloyi, Bm Thethwayo And Antoine F. Mulaba - Bafubiandi, University of Johannesburg, South Africa. under process circumstances. Chromium (VI) can cause cancer when disposed into the environment.

Recycling of used materials has become an important continuous process because of global warming and climate change. Of all processes in metallurgy, the pyrometallurgical industry can highly contribute to conserving the environment, this can be done by increasing the recycling of regained refractory bricks caused by its own operations (Magesh, Pappayee, \& Santhosh, 2016).

When the use of recycled refractory materials increases, this helps the manufactures to lower their prices of the products and helps the industries to give the recycling of their used materials more attention so that their input and waste disposal costs can be reduced (Magesh, Pappayee, \& Santhosh, 2016).

Refractory materials, as defined from the introduction, are materials that can withstand high temperatures. According to ASTM C71, refractories are non-metallic materials with physical and chemical properties that make them applicable to $538^{\circ} \mathrm{C}\left(1000^{\circ} \mathrm{F}\right.$ or $\left.811 \mathrm{~K}\right)$ and above-ground constructions. For lining of furnaces, kilns, inclinators and reactors, refractory materials are used. You can as well use refractory for other applications like moulds and crucibles that are used for metal and glass casting, and for surfacing flame deflector systems for rocket launch structures (Magesh, Pappayee, \& Santhosh, 2016).

It is necessary to select refractory lining material for a furnace with accurate knowledge of the refractory and refractory materials' chemical and physical properties. This knowledge also includes the stresses of the materials during service. Refractories face different type of stresses during their period of service. These stresses are given and discussed below:

\section{NEUTRAL REFRACTORIES}

These are chromium, alumina and graphite refractories, that are greatly used by the industries of metal due to their elevated melting temperature, price and the ability should be utilized in acidic and basic environments. When the production of chromia refractories has decreased because of the risks to the environment, refractories such as alumina are the mostly accessible neutral material.

These refractories are regarded acids and bases chemically well built. They are utilized in areas of which both the slag and the atmosphere are basic and acidic. Familiar examples for neutral refractory materials include:
$\checkmark$ Carbon graphite
$\checkmark$ Chromite
$\checkmark$ Alumina 
Graphite materials are less reactive and are mostly utilized in furnaces for metallurgical purposes in which it is possible to control the oxidation process (Magesh, Pappayee, \& Santhosh, 2016).

\section{BASIC REFRACTORIES}

Refractories that are basic are magnesia, doloma and spinel. They are most of the times coupled with carbon and graphite and are applicable in environments with high base. These refractories are capable of withstanding high temperatures of operation but are prone to hydration and operating temperatures but are susceptible to hydration, as a result, they need to be handled properly (Magesh, Pappayee, \& Santhosh, 2016).

These refractories are assaulted by acid slags, however, at very elevated temperatures they are robust to alkaline slags, powder and fumes. Since these refractories do not react with alkaline slags, they are considered important for furnace linings where the surrounding is alkaline, such as non-ferrous metallurgical operations.

The main significant basic raw materials are the following;

$\checkmark$ Magnesia $(\mathrm{MgO})$

$\checkmark$ Dolomite $(\mathrm{CaO}-\mathrm{MgO})$

$\checkmark$ Chromite

\section{ACIDIC REFRACTORIES}

Refractories of acids, like alumina-silicate substances, silica and zircon are commonly utilized for lower temperatures of operation compared to the other refractories. They are also more cost efficient in terms of production.

The chemical characteristics of the process of the furnace usually indicates the kind of refractory that is requisite. Conceptually, the acid refractories should not be utilized in correspondence with gases, fumes and basic slags whilst basic refractories are mostly suited in an alkaline surrounding. For a variety of causes, these guidelines are most of the times violated (Magesh, Pappayee, \& Santhosh, 2016).

Refractories can be categorized based on operating temperatures as shown in table 1 .

TABLE I: Types of refractories, operating temperatures and refractory examples (Magesh, Pappayee, \& Santhosh, 2016).

\begin{tabular}{|l|l|l|l|}
\hline S.No & $\begin{array}{l}\text { Type of } \\
\text { Refractories }\end{array}$ & $\begin{array}{l}\text { Refractoriness } \\
\left({ }^{\circ} \mathbf{C}\right)\end{array}$ & Examples \\
\hline 1 & $\begin{array}{l}\text { Low Heat Duty } \\
\text { Refractories }\end{array}$ & $1520-1630$ & $\begin{array}{l}\text { Silica } \\
\text { Bricks }\end{array}$ \\
\hline 2 & $\begin{array}{l}\text { Intermediate } \\
\text { Heat Duty } \\
\text { Refractories }\end{array}$ & $1630-1670$ & $\begin{array}{l}\text { Alumina } \\
\text { Bricks }\end{array}$ \\
\hline 3 & $\begin{array}{l}\text { High Heat Duty } \\
\text { Refractories }\end{array}$ & $1670-1730$ & $\begin{array}{l}\text { Chromite } \\
\text { Bricks }\end{array}$ \\
\hline 4 & $\begin{array}{l}\text { Super Heat } \\
\text { Duty } \\
\text { Refractories }\end{array}$ & $\begin{array}{l}\text { Magnesite } \\
\text { Bricks }\end{array}$ \\
\hline
\end{tabular}

As shown in the table 1, Alumina bricks can be used between $1630-1670^{\circ} \mathrm{C}$, whereas magnesite can be used at a temperature above $1730^{\circ} \mathrm{C}$, hence magnesite is the widely used refractory.

The most widely used refractories in the world are clays and refractories that contain magnesia. Clay refractories are commonly utilized in a broad range of sectors and applications, whereas refractories of magnesia are extremely significant in the production of steel. Doloma refractories only contribute $3 \%$ of their usage worldwide and are connected to the steel industries where magnesia-chrome bricks are greatly substituted by the doloma refractories (Magesh, Pappayee, \& Santhosh, 2016).

The production of refectories in the world is around 35-40 million tons per year.

\section{ALUMINA REFRACTORIES}

Andalusite $\left(\mathrm{Al}_{2} \mathrm{O}_{3} \mathrm{SiO}_{2}\right)$ was commonly used as a high-quality raw material of anhydrous alumino - silicates in mullite products. Refractories that have been made from andalusite have excellent mechanical properties and can resist to thermal shock at high temperatures. They are as well used in other high temperature industries. When andalusite is fired at higher temperature, it is transformed into mullite $\left(3 \mathrm{Al}_{2} \mathrm{O}_{3} \cdot 2 \mathrm{SiO}_{2}\right)$ and silica rich glass. When the transformation of mullite from andalusite is complete, mullite generates about $80 \%$ and glass about $20 \%$ (Li, et al.). The formation of mullite is given by the chemical reaction below:

$\mathrm{Al}_{2} \mathrm{O}_{3} \mathrm{SiO}_{2} \longrightarrow 3 \mathrm{Al}_{2} \mathrm{O}_{3} \cdot 2 \mathrm{SiO}_{2}+\mathrm{SiO}_{2}$, this reaction occurs at a temperature of $1200^{\circ} \mathrm{C}$.

The phase diagram below shows the phases of an mullite and silica refractory. Pure mullite melts above $2000^{\circ} \mathrm{C}$, whereas silica melts at about $1595^{\circ} \mathrm{C}$. This diagram shows that mullite is a better refractory than that of a silica

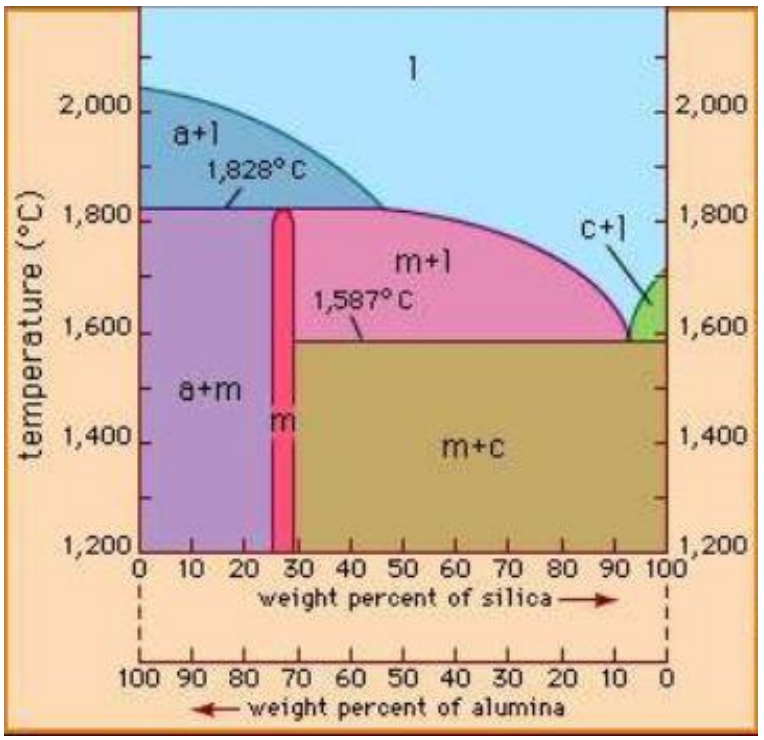

Fig 1: Phase diagram for mullite and silica

Refractory clays like chamotte are also utilised in refractories globally and in manufacturing companies. 
Refractories such as Bauxite $\left(\mathrm{Al}(\mathrm{OH})_{3}\right)$, which are rich in alumina, are primarily used in production of steel and electric arc furnaces (Horckmans, Nielsen, Dierckx, \& Ducastel, 2019).

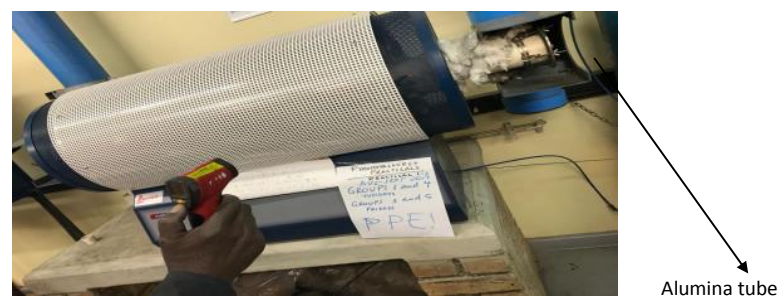

Fig 2: Furnace in operation with alumina refractory as a lining.

The fig. above shows the furnace in operation with the lining of the furnace being the alumina tube. The tube is exposed in extremely higher temperatures.

\section{ALUMINA SILICATES}

Companies that produce brass use alumina silicate refractories in melting furnaces. Typically, most of the companies dispose their refractories. Most of the acid refractory materials can be described on the system $\mathrm{Al}_{2} \mathrm{O}_{3}-\mathrm{SiO}_{2}$. Due to the high liquidus temperature and the high temperature of the eutectic $\left(1595{ }^{\circ} \mathrm{C}\right)$, alumino-silicates are generally considered as having good refractory properties, although their performance can be significantly affected by impurities. Hexavalent chromium causes health problems including allergic reactions and skin rash. Magnesia-alumina and alumina silicates were considered as suitable replacement owing to their good erosion-corrosion properties (Raghavendra, 2008).

\section{Methods OF RECYCLING}

\section{A. Hand Sorting}

Color sorting systems has been developed to sort refractories. The attempt of using cyber camera to clarify based on the grey scale was implemented. This attempt has significant drawbacks, causing the bricks having to be compressed and analyzed individually on 5 seconds intervals in between each analysis. For manufacturing execution, this is not fitting. Because of the restricted knowledge present for this process, this looks to be commonly directed of detaching a variety of standards of refractories for a certain kind, thus this process cannot overtake the labor or manual work sorting process.

The discoloration of exhausted refractories inhibits color sorting refractories because of dust layers and alike imagery of specific chemical refractories. An instance to this would be $\mathrm{AMC}, \mathrm{MgO}-\mathrm{C}$ and doloma-carbon that altogether possess the same black appearance because of graphite appearance.

\section{B. Laser Induced Breakdown Spectroscopy (LIBS)}

Many sorting procedures were established in the previous few years, utilizing LIBS (Laser Induced Breakdown Spectroscopy) as the substance recognition process. LIBS utilize a laser that is pulsed to remove a tiny fraction of the layer of a substance. The substance is put under temperature conditions of over $10000^{\circ} \mathrm{C}$. the recognition is at the basis of the discovery of element-particular spectral emission lines.

Another LIBS system was developed and was based on LIBS capacities that are linear to analyze and sort refractory substances based on $\mathrm{MgO} . \mathrm{Al}_{2} \mathrm{O}_{3}$ and $\mathrm{SiO}_{2}$ amount in the aluminium-carbon, $\mathrm{AMC}$ and $\mathrm{MgO}$. Layers that are contaminated are extracted using labor work prior to the bricks going into the process, and classification is conducted with the use of machines here. This process goes up to $>98 \%$ of classification correctness.

\section{Leaching And Flotation}

Magnesia-chrome refractories have been widely used in copper smelting furnaces until they were identified as hazardous waste. In one study, the spent refractory linings were subjected to water leaching to remove sulphates. The Sulphur ion removal also effectively dissolves chromium and the remaining residue was re-usable.

Leaching and flotation processes were used to recycle copper contaminated bricks from copper smelting furnaces. The residue was then reused (Raghavendra, 2008).

\section{CONCLUSION}

According to the literature, the recycling of refractories possible. The collected spent refractory tubes from pyrometallurgical labs will be crushed and then milled to reduce the particle size suitable for shaking table and magnetic separation. Shaking table and magnetic separation will be used to separate the alumina from the impurities in the tubes.

\section{REFERENCES}

[1] Horckmans, L., Nielsen, P., Dierckx, P., \& Ducastel, A. (2019). Recycling of refractory bricks used in basic steelmaking: A review. Resources, Conservation and Recycling, 140, 297-304. https://doi.org/10.1016/j.resconrec.2018.09.025

[2] Li, S., Ye, G., Zhang, Y., Zang, Y., Song, X., \& Zhang, C. (n.d.). Effects of particles and impurities on mutillization of andalusite. Zhengzhou.

[3] Magesh, K. M., Pappayee, N., \& Santhosh, K. (2016, June). Reduce, Reuse and Recycling Technology for Refractories in Cement Industries. International Journal of Innovative Research in Science, Engineering and Technology, 5(6).

[4] Raghavendra, P. K. (2008). Recovery of materials from recycling. 